\title{
Microbiological profile of different types of salads from hospital kitchens
}

\author{
Perfil microbiológico de diferentes tipos de saladas provenientes de \\ cozinhas hospitalares \\ Letícia Borges Nunes Correia ${ }^{*}$, Fábio Sossai Possebon', Ricardo Seiti Yamatogi', \\ José Carlos de Figueiredo Pantoja', Otávio Augusto Martins', Gilda Pinto Amaral', \\ Germano Francisco Biondi ${ }^{1}$
}

\begin{abstract}
The objective of this work was to verify the microbiological profile of different types of salads from hospital kitchens. During the period from 2010 to 2014, the Public Food Guidance Service (SOAP) received 641 samples of salads from two public hospitals in the Central West region of the São Paulo state, where they were submitted to microbiological analysis in order to determine the most probable number (MPN) of coliforms at 35 and $45^{\circ} \mathrm{C}$, carry out Salmonella spp. study and coagulase-positive staphylococci count. The results showed that in $30.56 \%$ of samples the coliform count at $35^{\circ} \mathrm{C}$ was above $1,100 \mathrm{MPN} / \mathrm{g}$ and $12.17 \%$ of samples presented coliforms at $45^{\circ} \mathrm{C}$ above $100 \mathrm{MPN} / \mathrm{g}$, which is the maximum limit established by Brazilian law. The prevalence of contaminated samples among those without heat treatment was at $97.44 \%$, and for samples with heat treatment the prevalence was at $2.56 \%$ for both cooked and braised foods. All samples were negative for Salmonella spp. presence and showed coagulase-positive staphylococci count at $<1.0 \times 10^{2} \mathrm{UFC} / \mathrm{g}$. Although no pathogenic agents were found, the high count for indicator microorganisms in a large number of samples suggests that the practices of obtaining and manipulating these foods are inadequate, facilitating the risk of contamination with pathogens, including other agents not included in this research. Thus, food and nutrition units must pay attention to food preparation procedures, especially since these meals are served to indoor patients.
\end{abstract}

KEYWORDS: coliforms; Staphylococci; hospital; vegetables; Salmonella spp.
RESUMO: O objetivo deste trabalho foi verificar o perfil microbiológico de diferentes tipos de saladas provenientes de cozinhas hospitalares. No período de 2010 a 2014, o Serviço de Orientaçáo à Alimentação Pública (SOAP) recebeu 641 amostras de saladas provenientes de dois hospitais públicos da regiāo centro-oeste do estado de São Paulo, onde foram submetidas às análises microbiológicas para a determinação do número mais provável (NMP) de coliformes a 35 e $45^{\circ} \mathrm{C}$, pesquisa de Salmonella spp. e contagem de estafilococos coagulase positiva. Os resultados revelaram que em $30,56 \%$ das amostras a contagem de coliformes a $35^{\circ} \mathrm{C}$ foi maior que $1.100 \mathrm{NMP} / \mathrm{g}$, e $12,17 \%$ apresentaram coliformes a $45^{\circ} \mathrm{C}$ acima de $100 \mathrm{NMP} / g$, limite máximo estabelecido pela legislação brasileira. A prevalência de amostras contaminadas sem tratamento térmico foi de $97,44 \%$ e de $2,56 \%$ para amostras com tratamento térmico, cozidas ou refogadas. Todas as amostras foram negativas para presença de Salmonella spp. e apresentaram contagem de estafilococos coagulase positiva $<1,0 \times 10^{2} \mathrm{UFC/g}$. Embora não tenham sido encontrados agentes patogênicos, as altas contagens de micro-organismos indicadores em grande parte das amostras sugerem que as práticas de obtenção e manipulação desses alimentos estão inadequadas, possibilitando risco de contaminação por patógenos, inclusive outros agentes não contemplados nesta pesquisa. Portanto, as unidades de alimentação e nutrição hospitalares devem se atentar quanto aos procedimentos de preparo de alimentos, sobretudo porque essas refeições são servidas a indivíduos hospitalizados.

PALAVRAS-CHAVE: coliformes; estafilococos; hospital; vegetais; Salmonella spp. 


\section{INTRODUCTION}

Vegetables are herbaceous plants whose part(s) is (are) used in its natural form by humans as food (BRASIL, 1978). In accordance with the comestible part, these can be classified as tuberoses (roots, bulbs and tubers), fruits (vegetables and seeds) and greens (leaves, stems and flowers) (BEVILACQUA, 2014; FAO, 2014). These vegetables are indispensable in human diet, acting as adjuvants in the prevention and treatment of diseases (OYEBODE et al., 2014; WANG et al., 2014). However, there has been an outbreak of foodborne diseases associated with vegetable consumption (TABAN; HALKMAN, 2011; BENNETT, 2014).

The majority of foodborne diseases are caused by biological agents that can generate infections, poisoning and toxinfections (BRASIL, 2014). Estimates from Centers for Disease Control and Prevention (CDC) revealed that 48 millions of Americans get ill each year as a result of foodborne diseases, 128,000 are hospitalized and 3,000 die. From 2010 to 2014, 114 outbreaks of foodborne diseases occurred in Brazilian hospital units, while in the United States only 108 outbreaks were registered during the period from 1998 to 2012 (BRASIL, 2014; CDC, 2014).

KOZAK et al. (2013) verified the outbreaks associated with fresh vegetables and fruits in Canada during the period from 2001 to 2009 , where 27 items of plant origin were associated with the occurrence of 1,549 outbreaks of foodborne diseases. Among the most commonly encountered bacteria were Salmonella spp. (50\%), Escherichia coli (33\%) and Shigella spp. (17\%).

There is no specific syndrome associated with foodborne diseases. However, as they enter the body orally, the initial clinical symptoms are associated with the gastrointestinal tract, although extraintestinal symptoms are also possible, affecting several organs and systems (BRASIL, 2010; CDC, 2012).

The contamination of vegetables can occur during any production phase and can have its origin in the primary phase as a result of contamination of the equipment and the environment (soil, water and air), as well as during, before and after harvesting (CEUPPENS et al., 2014). At the same time, food manipulators, utensils and contact surfaces are all important sources of contamination during the preparation of meals, which may cause hazards of biological, chemical or physical nature in a salad ready to be consumed (BALZARETTI; MARZANO, 2013; BRANDÁO et al., 2014).

In order to ensure the safety of vegetables, as well as dishes prepared using these vegetables, the National Sanitary Surveillance Agency (ANVISA), by way of its Resolution No. 12/01, established microbiological standards, requiring complete absence of Salmonella spp. in $25 \mathrm{~g}$ of product, $10^{2} \mathrm{NMP} / \mathrm{g}$ of coliforms at $45^{\circ} \mathrm{C}$ and coagulate-positive staphylococci count at $<1.0 \times 10^{2} \mathrm{UFC/g}$ (BRASIL, 2001).

Considering the characteristics attributed to the studied food, like the presence of vegetables in the composition of dishes that make part of dietary habits of Brazilians, especially in hospital diets, as well as their relevance for health promotion and as adjuvants in the treatment of some diseases, when speaking about outbreaks of foodborne diseases, research is needed to obtain information about the microbiological profile of meals served in Hospital Food and Nutrition Units (UAN).

Thus, the objective of this study was to verify the microbiological profile of different types of salads from hospital kitchens of two public hospitals of the Central West region of São Paulo state, by determining the Most Probable Number (MPN) of coliforms at 35 and $45^{\circ} \mathrm{C}$, Salmonella spp. research and coagulate-positive staphylococci count.

\section{MATERIAL AND METHODS}

From January 2010 to July 2014, the Public Food Guidance Service (SOAP) of Botucatu campus of Faculty of Veterinarian Medicine and Animal Science (FMVZ) received 641 samples of salads from hospitals located in Botucatu and Bauru regions of São Paulo state. These were put in a sterile collector bag and sent in an exothermic box to microbiological laboratory to realize the following tests: determination of the MPN of coliforms at 35 and $45^{\circ} \mathrm{C}$, Salmonella spp. study and coagulate-positive staphylococci count.

\section{Preparation and Dilution of Samples}

The samples were weighed using analytical balance (Gehaka BK 3000, Gehaka, Brazil) under a laminar flow hood (Veco Bioseg 12 , Veco, United States). Immediately after cleaning the packages with $70 \%$ alcohol, $25 \mathrm{~g}$ of homogenized samples were weighed aseptically and $225 \mathrm{~mL}$ of $0.1 \%$ Oxoid buffered peptone water was added, followed by homogenization realized in Stomacher. One $\mathrm{mL}$ of this $10^{-1}$ dilution was transferred to a threaded tube containing $9 \mathrm{~mL}$ of $0,9 \%$ saline solution, which allowed to obtain a $10^{-2}$ dilution, and after repeating the procedure $-\mathrm{a} 10^{-3}$ dilution.

\section{Microbiological Analysis}

The analytical methods for the determination of the MPN of coliforms at 35 and $45^{\circ} \mathrm{C}$ and for coagulate-positive staphylococci count were carried out in accordance with the description given in Normative Instruction No. 62 of the Ministry of Agriculture, Livestock and Supply (MAPA) (BRASIL, 2003). The Salmonella spp. study was conducted according to the methodology recommended by the Bacteriological Analytical Manual (ANDREWS et al., 2011).

\section{Data Collection}

The results were collected through verification of reports generated by the Sample Management for Analysis Program 
(PGAA) and transferred to an Excel 2010 spreadsheet for further statistical analysis.

\section{Statistical Analysis}

The distribution of MPN values for coliforms at $35^{\circ} \mathrm{C}$ was verified through quantile and box plot charts, showing the absence of normality. Statistical analysis was performed using non-parametric Wilcoxon test for independent samples via PROC NPAR1WAY (SAS, 2011), since the logarithmic scale was not effective for normalization. At the same time, the results were depicted graphically using the logarithmic scale for a better visualization.

A logistic regression model was used via PROC GLIMMIX (SAS, 2011) in order to estimate the chances of finding samples considered to be positive for coliforms at $45^{\circ} \mathrm{C}$ as an explanatory variable function: heat processing and vegetable category. The interaction term between heat processing and vegetable category was tested in this model. The results were presented in percentage. For all tests, the significance level was set at $5 \%(\mathrm{p}<0.05)$.

\section{RESULTS}

From January 2010 to July 2014, 641 samples of salads from hospital kitchens of two public hospitals from Central West region of São Paulo state were analyzed. Of these, 607 $(94.70 \%)$ did not receive any type of heat treatment (SPT) and $34(5.30 \%)$ did pass through a heat treatment process, which means cooking or braising (CPT).

According to the part of vegetables intended for human consumption, the samples were categorized as leaves, fruits and tuberoses. A fourth group called "mixed" was created to categorize samples composed of more than one ingredient (Table 1).

All 641 samples (100\%) showed absence of Salmonella spp. in $25 \mathrm{~g}$ of product and the coagulate-positive staphylococci count was $<1.0 \times 10^{2} \mathrm{UFC} / \mathrm{g}$. Of the total amount of samples, $196(30.60 \%)$ showed presence of coliforms at $35^{\circ} \mathrm{C}$ above $1,100 \mathrm{MPN} / \mathrm{g}$. The median value (min.-max.) was $93(0.3-24,000)$ for SPT samples and $10(3-2,400)$ for CPT samples $(\mathrm{p}=0.01)$.

Figure 1 shows the MPN of coliforms at $35^{\circ} \mathrm{C}$ in salads for respective category. Among the four analyzed categories, only the leaves showed statistical difference in comparison with mixed and tuberoses categories $(\mathrm{p}<0.05)$. The total coliform-positive percentage above $100 \mathrm{MPN} / \mathrm{g}$, which is a standard limit set by current legislation, for samples at $45^{\circ} \mathrm{C}$ was $78(12.17 \%)$, in which $76(97.44 \%)$ were heat treatment (SPT) samples and $2(2.56 \%)$ were cooking or brasing (CPT) samples. The chances of SPT samples to be positive were 6.98 times greater when compared to samples of CPT group, with a confidence interval of $95 \%$ CI $1.48-32.65$, showing statistical difference $(\mathrm{p}<0.05)$.
Table 1. A percentage of SPT and CPT samples, and total percentage of salads analyzed at SOAP during the 2010-2014 period.

\begin{tabular}{|c|c|c|c|}
\hline Samples & SPT (\%) & СРТ (\%) & Total (\%) \\
\hline Fruits & 26 (89.65) & $3(10.34)$ & $29(4.52)$ \\
\hline Pumpkin & $1(50)$ & $1(50)$ & $2(0.31)$ \\
\hline Squash & $1(100)$ & $\mathrm{O}(0)$ & $1(0.16)$ \\
\hline Eggplant & $6(0.75)$ & $2(25)$ & $8(1.25)$ \\
\hline Tomato & $14(100)$ & $\mathrm{O}(0)$ & $14(2.18)$ \\
\hline Cucumber & $4(100)$ & $\mathrm{O}(0)$ & $4(0.62)$ \\
\hline Leaves & $521(98.67)$ & $7(1.32)$ & $528(82.37)$ \\
\hline Chard & $34(97.14)$ & $1(2.86)$ & $35(5.46)$ \\
\hline Cress & $48(100)$ & $\mathrm{O}(0)$ & $48(7.49)$ \\
\hline Lettuce & $155(100)$ & $\mathrm{O}(0)$ & $155(24.18)$ \\
\hline $\begin{array}{l}\text { Romaine } \\
\text { lettuce }\end{array}$ & $87(100)$ & $\mathrm{O}(0)$ & $87(13.57)$ \\
\hline Chive & $2(100)$ & $\mathrm{O}(0)$ & $2(0.31)$ \\
\hline Coriander & $9(100)$ & $\mathrm{O}(0)$ & $9(1,40)$ \\
\hline Chicory & $9(100)$ & $\mathrm{O}(0)$ & $9(1,40)$ \\
\hline Kale & $25(83.33)$ & $5(16.67)$ & $30(4.68)$ \\
\hline $\begin{array}{l}\text { Endive/ } \\
\text { Escarole }\end{array}$ & $42(100)$ & $\mathrm{O}(0)$ & $42(6.55)$ \\
\hline Spinach & $2(100)$ & $O(0)$ & $2(0.31)$ \\
\hline Cabbage & $37(97.37)$ & $1(2.63)$ & $38(5.93)$ \\
\hline Ruccola & $69(100)$ & $\mathrm{O}(0)$ & $69(10.76)$ \\
\hline Parsley & $2(100)$ & $\mathrm{O}(0)$ & $2(0.31)$ \\
\hline Tuberoses & $26(76.47)$ & $8(23.52)$ & $34(5.30)$ \\
\hline Potato & $\mathrm{O}(0)$ & $2(100)$ & $2(0.31)$ \\
\hline Beet & $11(100)$ & $\mathrm{O}(0)$ & $11(1.72)$ \\
\hline Onions & $1(100)$ & $0(0)$ & $1(0.16)$ \\
\hline Carrots & $14(70)$ & $6(30)$ & $20(3.12)$ \\
\hline Mixed & $34(68)$ & $16(32)$ & $50(7.8)$ \\
\hline Total & $607(94.70)$ & $34(5.30)$ & $641(100)$ \\
\hline
\end{tabular}

SPT: no heat processing; CPT: heat processed.

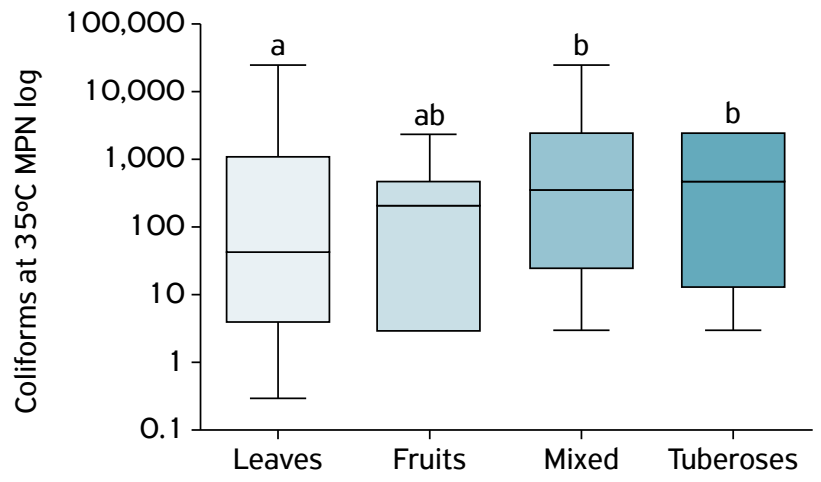

Different letters indicate statistical difference $(p<0.05)$.

Figure 1. Coliforms at $35^{\circ} \mathrm{C}$ MPN log for samples distributed in categories. 
In Table 2, the tuberose vegetables showed the largest percentage of positivity for the presence of coliforms at $45^{\circ} \mathrm{C}$ above the limits established by current legislation, with $15(44.12 \%)$ showing statistical difference in relation to other categories $(\mathrm{p}<0.05)$. The tuberoses had $10.53(4.73-23.55)$ more chances to be positive than leaves, 8.93 (2.17-37.03) in relation to fruits and $3.55(1.31-10.00)$ when compared to mixed category. There was also statistical difference $(\mathrm{p}<0.05)$ between mixed and leaves categories, in which the former one had 2.98 (1.32-6.71) times more chances to be positive than the latter one. There was no statistical difference between fruits and leaves neither between mixed and fruits $(p>0.05)$.

\section{DISCUSSION}

Although there is no standard in Brazilian legislation concerning the MPN of coliforms at $35^{\circ} \mathrm{C}$, an elevated number of these microorganisms in prepared meals ready to be consumed provides information about the hygiene practices before, during and after food processing (JAY, 2005; OLAIMAT; HOLLEY, 2012).

In addition to obtained results, other authors report the occurrence of coliforms at $35^{\circ} \mathrm{C}$ with values above $1,100 \mathrm{MPN} / \mathrm{g}$ in this type of product (LEÓN et al., 2013; BRANDÃO et al., 2014), since some varieties of bacteria belonging to this group are found naturally in fresh vegetables and soil (FRANCO; LANDGRAF, 2002; JAY, 2005). As for the MPN of coliforms at $45^{\circ}$, the results are similar to those obtained by BRANDÁO et al. (2014) in Brazil, showing a 20\% prevalence of values above the standard limits in salad samples from restaurants, although lower than the results obtained in other studies conducted in Brazil, which showed a prevalence of $70 \%$ in samples of minimally processed salads originating from supermarkets (FRÖDER et al., 2007) and $100 \%$ in salads originating from restaurants (ROCHA et al., 2014) with values above $100 \mathrm{MPN} / \mathrm{g}$.

The lesser prevalence of coliforms at $45^{\circ} \mathrm{C}$ in salads that were submitted to a heat treatment process is evidence of the

Table 2. Number and percentage of samples above the $10^{2} \mathrm{MPN} / \mathrm{g}$ limit for coliforms at $45^{\circ} \mathrm{C}$, established by Resolution No. 12/01, divided by category.

\begin{tabular}{lccc} 
Class & N Total & N Pos & $\%$ Pos \\
\hline Tuberoses & 34 & 15 & $44.12^{\mathrm{a}}$ \\
\hline Mixed & 50 & 9 & $18^{\mathrm{b}}$ \\
\hline Fruits & 29 & 3 & $10.34^{\mathrm{bc}}$ \\
\hline Leaves & 528 & 51 & 9.66 \\
\hline Total & 641 & 78 & 12.17 \\
\hline
\end{tabular}

$\mathrm{N}$ Total: Total number of samples in a category; N Pos: Number of positive samples in a category; \% Pos: Percentage of positive samples in a category; Different letters ${ }^{(a, b, c)}$ indicate statistical difference $(p<0.05)$. importance of temperature in maintaining the products safe for consumption (ALMUALLA et al., 2010; FARIAS et al., 2011). The lesser contamination of cooked salads in comparison with the raw ones was also noted in restaurants of Mexico (LEÓN et al., 2013). In accordance with the Sanitary Vigilance Center Ordinance (CVS-5) dated 04/2013, the temperature of cold meals ready for consumption should be $10^{\circ} \mathrm{C}$ with a validity term of four hours, or between 10 and $21^{\circ} \mathrm{C}$, with a validity term of two hours (SÃO PAULO, 2013).

Salads that had tubers in their composition showed greater occurrence of coliforms. This result may be associated with the preparation method, as the tuberose vegetables consumed raw are subjected to more manipulation, such as peeling, cutting and grating/shredding, which results in freshly cut vegetables exhibiting higher moisture content and greater nutrient availability, apart from increased contact surfaces, favoring the growth of microorganisms (JAY, 2005; OLAIMAT; HOLLEY, 2012). These vegetables are also more exposed to contaminants during the initial production phase, since the part intended for consumption is found beneath the surface of the soil (BEVILACQUA, 2014; FAO, 2014). Thus, if directly after the harvesting stage some effective hygienic measures are not adopted, the final product may end up containing contaminants originating from the cultivation phase, since the soil and fertilizers are sources of contamination during the primary production phase (OLAIMAT; HOLLEY, 2012; CEUPPENS et al., 2014).

CEUPPENS et al. (2014), after analyzing the materials used in the production of lettuce in Brazil, showed that the prevalence of Salmonella spp. in organic fertilizers (manure) was $5,6 \%$, while in the soil it was $2,6 \%$. They also showed a strong relationship between the elevated number of coliforms at $45^{\circ} \mathrm{C}$ and the increase in the prevalence of pathogens.

Irrigation water is another important source of contamination for raw vegetables during the initial production phase (OLAIMAT; HOLLEY, 2012; CEUPPENS et al., 2014). In accordance with Resolution No. 357/05 of the National Council for Environment (CONAMA), the maximum limit of coliforms at $45^{\circ} \mathrm{C}$ for water used in irrigation of vegetables intended for consumption is $200 \mathrm{MPN} / 100 \mathrm{~mL}$ (BRASIL, 2005). Research conducted in Brazil in the regions of Botucatu/ SP (FRAVET; CRUZ, 2007) and Brasília/DF (ABREU et al., 2010 ) revealed that $100 \%$ of irrigation water used in plots did not meet the requirements of the legislation in respect of MPN of coliforms at $45^{\circ} \mathrm{C}$.

The presence of coliforms in vegetables does not necessarily mean that there was a fecal contamination, because some strains of the Enterobacter and Klebsiella genus possess the same characteristics as coliforms at $45^{\circ} \mathrm{C}$ and can be found in other environments, like fresh vegetables themselves, as well as soil (FRANCO; LANDGRAF, 2002; JAY, 2005). At the same time, high levels may compromise sensorial and nutritional quality, apart from being an evidence of unsatisfactory 
hygienic practices during the stage of washing the vegetables for preparation of salads (BRANDÁO et al., 2014).

During the preparation of salads, the food manipulators and contact surfaces are both important sources of contamination (BALZARETTI; MARZANO, 2013; BRANDÃO et al., 2014). In Brazil, RIBEIRO et al. (2014) analyzed the sanitary conditions of home kitchens and found that 47.5 and $3.8 \%$ of the hands of the person who, among the residents, was most likely to handle the food were contaminated with coliforms at $35^{\circ} \mathrm{C}$ and Escherichia coli, respectively. In Italy, BALZARETTI; MARZANO (2013) evaluated the hygienic conditions of 44 UAN of three airports and found that 8.4 and $3.5 \%$ of hand washing by food handlers showed unsatisfactory limits with regard to total bacterial coagulate-positive staphylococci count, respectively.

The washing of vegetables helps reduce the number of microorganisms (JAY, 2005). RODRIGUES et al. (2011) evaluated two techniques used in the cleaning of vegetables and fruits, one of them made use of water and soap and the other one a $1 \%$ sodium hypochlorite solution with a $100-250 \mathrm{ppm}$ active chlorine content. Both cleaning procedures lasted for 15 minutes. Only the later technique proved to be efficient in the quantitative reduction of microorganisms.

Although Salmonella spp. is the most commonly biological agent associated with outbreaks of foodborne diseases in Brazil (BENNETT, 2014; BRASIL, 2014), this study showed a notable absence of it in $25 \mathrm{~g}$, which is in line with the results obtained by BRANDÃO et al. (2014). At the same time, ARAÚJO et al. (2011) obtained a 100\% prevalence of Salmonella spp. in raw salads of restaurants in Pombal, in Paraiba state. In other studies carried out in UAN by FRÖDER et al. (2007), DIAS et al. (2011) and MAISTRO et al. (2012), the prevalence of Salmonella spp. in salad samples was 3, 28.57 and $16.86 \%$, respectively. The presence of Salmonella spp. was also observed in salads from restaurants in Mexico, where GÓMEZ-ALDAPA et al. (2013) found a prevalence of $6.8 \%$ in raw salads, while LEÓN et al. (2013) found a prevalence of $1 \%$ in cooked salads.

The meals served by hospital Food and Nutrition Units must be safe in all respects, especially with regard to hygiene.
Although foodborne diseases affect any type of person, some population groups are more susceptible than others, which is the case of indoor patients with impaired immune systems, whose state of health may be aggravated by ingestion of contaminated food (KONECKA-MATYJEK et al., 2012; SARKER et al., 2014).

The results of previous research performed with salad samples from different types of establishments are comparable with those shown by present study, as all of these establishments are considered Food and Nutrition Units and must meet the same hygienic and sanitary parameters (PINTO et al., 2013).

\section{CONCLUSION}

The microbiological profile of salad samples from kitchens of two public hospitals of the Central West region of São Paulo state proved to be compatible with current legislation regarding Salmonella spp. and coagulate-positive staphylococci count. Although no pathogenic agents were found, the high count of indicator microorganisms in the majority of samples suggests that the practices of obtaining and manipulating these products are inadequate, allowing the risk of contamination by pathogens, including other agents not included in this research. Therefore, hospital Food and Nutrition Units must pay attention to food preparation procedures, especially since these meals are served to hospitalized individuals.

\section{ACKNOWLEDGEMENTS}

We express our gratitude to Public Food Guidance Service (SOAP) of Botucatu campus of Faculty of Veterinarian Medicine and Animal Science and to Coordination for the Improvement of Higher Education Personnel (CAPES) for financial support, as well as to teachers and students who in some way or another contributed to the consolidation of this project.

\section{REFERENCES}

ABREU, I.M.O.; JUNQUEIRA, A.M.R.; PEIXOTO, J.R.; OLIVEIRA, S.A. Qualidade microbiológica e produtividade de alface sob adubação química e orgânica. Ciência e Tecnologia de Alimentos, Campinas, v.30, n.1, p.108-118, 2010.

ALMUALLA, N.A.; LALEYE, L.C.; ABUSHELAIBI, A.A.; AL-QASSEMI, R.A.; WASESA, A.A.; BABOUCARR, J. Aspects of the microbiological quality and safety of ready-to-eat foods in Sharjah supermarkets in the United Arab Emirates. Journal of Food Protection, Des Moines, v.73, n.7, p.1328-1331, 2010.
ANDREWS, W.H.; JACOBSON, A.; HAMMACK, T. Salmonella. In: Food and Drug Administration. Bacteriological analytical manual. 8. ed. Gaithersburg: AOAC International, 2011 . Available from: <http:// www.fda.gov/Food/FoodScienceResearch/LaboratoryMethods/ ucm070149.htm>. Cited at: 10 Mar. 2015.

ARAÚJO, M.S.; RODRIGUES, M.S.A.; SILVA, R.A.S.; MARTINS, W.F.; ARAÚJO, A.S. Análise microbiológica de saladas servidas em restaurantes da cidade de Pombal-PB. Caderno Verde de Agroecologia e Desenvolvimento Sustentável, Pombal, v. 1, n.1, p.1, 2011. 
BALZARETTI, C.M.; MARZANO, M.A. Prevention of travelrelated foodborne diseases: Microbiological risk assessment of food handlers and ready-to-eat foods in northern Italy airport restaurants. Food control, Guildford, v.29, n. 1, p.202-207, 2013.

BENNETT, S. Increasing Number and Greater Morbidity and Mortality Associated with Multistate Foodborne Disease Outbreaks - United States, 1973-2010. In: 2014 ANNUAL MEETING, 2014, Tóquio, International Association for Food Protection, Des Moines, 2014.

BEVILACQUA, H.E.C.R. Manual da horta. [S.I.: s.n.], 2014.

BRANDÃO, M.L.; ALMEIDA, D.O.; BISPO, F.C.; BRICIO, S.M.; MARIN, V.A.; MIAGOSTOVICH, M.P. Assessment of microbiological contamination of fresh, minimally processed, and ready to eat lettuces (Lactuca sativa), Rio de Janeiro State, Brazil. Journal of Food Science, Chicago, v.79, n.5, p.961-966, 2014.

BRASIL. Congresso. Senado. Resolução n. ${ }^{12}$, de 24 de julho de 1978. Aprova as Normas Técnicas Especiais, do Estado de São Paulo, revistas pela Comissão Nacional de Normas e Padrões para Alimentos - CNNPA, relativas a alimentos e bebidas, para efeito em todo território brasileiro. Diário Oficial [da] República Federativa do Brasil, Poder Executivo, Brasília, DF, Seção 410, p. 2.

BRASIL. Congresso. Senado. Resolução n. ${ }^{\circ} 12$, de 2 de janeiro de 2001. Aprova o Regulamento Técnico sobre padrões microbiológicos para alimentos. Diário Oficial [da] República Federativa do Brasil, Poder Executivo, Brasília, DF, 10 jan. 2001. Seção 1, p. 39.

BRASIL. Ministério da Agricultura, Pecuária e Abastecimento. Instrução Normativa n. ${ }^{\circ} 62$, de 26 de agosto de 2003. Aprova os métodos analíticos oficiais para controle de produtos de origem animal e água. Brasília, DF, 2003. 194p.

BRASIL. Ministério da Saúde. Manual integrado de vigilância, prevenção e controle de doenças transmitidas por alimentos. Brasília, DF, 2010. 157p.

BRASIL. Ministério da Saúde. Vigilância epidemiológica das doenças transmitidas por alimentos. Brasília, DF, 2014. Disponível em: <http://www.anrbrasil.org.br/new/pdfs/2014/3_ PAINEL_1_ApresentacaoRejaneAlvesVigilanciaEpidemiologica -VE-DTA-Agosto_2014_PDF.pdf>. Acesso em: 10 dez. 2014.

BRASIL. Resolução n. ${ }^{\circ}$ 357, de 17 de março de 2005. Dispõe sobre a classificação dos corpos de água e diretrizes ambientais para o seu enquadramento, bem como estabelece as condições e padrões de lançamento de efluentes, e dá outras providências. Coleção de Leis da República Federativa do Brasil, Brasília, DF, v. 53, p. 58-63, mar. 2005.

CDC - CENTERS FOR DISEASE CONTROL AND PREVENTION. Food safety, foodborne disease. Atlanta, 2012. Disponível em: <http:// www.cdc.gov/foodsafety/facts.html>. Acesso em: 21 jan. 2015.

CDC - CENTERS FOR DISEASE CONTROL AND PREVETION. Foodborne outbreak online database (food). Atlanta, 2014. Disponível em: <http://wwwn.cdc.gov/foodborneoutbreaks/ Default.aspx>. Acesso em: 15 fev. 2015.

CEUPPENS, S.; HESSEL, C.T.; RODRIGUES, R.Q.; BARTZ, S.; TONDO, E.C.; UYTTENDAELE, M. Microbiological quality and safety assessment of lettuce production in Brazil. International Journal of Food Microbiology, Amsterdã, v. 181, p.67-76, 2014.

DIAS, H.S.; PINTO JÚNIOR, W.R.; ZANUTO, M.E.; FONSECA, N.T.; OLIVEIRA, A.S.; PORTO, S.S. Avaliação microbiológica de saladas de vegetais com maionese, servidas em restaurantes comerciais self-service por quilo, na região Central de Vitória da Conquista, BA. Revista Higiene Alimentar, São Paulo, v.25, n. 194/195, p.1-2, 2011.

FAO - FOOD AND AGRICULTURE ORGANIZATION OF THE UNITED NATIONS. Consultancy report on first extension staff training in horticulture. Basic understanding of horticulture. 2014. Disponível em: <http://www.fao.org/docrep/x5642e/x5642e06.htm>. Acesso em: 20 jan. 2015.

FARIAS, J.K.R.; PEREIRA, M.M.S.; FIGUEIREDO, E.L. Avaliação de boas práticas e contagem microbiológica das refeições de uma unidade de alimentação hospitalar, do município de São Miguel do Guamá - Pará. Alimentos e Nutrição, Araraquara, v.22, n.1, p. $113-119,2011$.

FRANCO, B.D.G.M.; LANDGRAF, M. Microbiologia dos Alimentos. 2. ed. São Paulo: Atheneu, 2002. 182 p.

FRAVET, A.M.M.F.; CRUZ, R.L. Qualidade da água utilizada para a irrigação de hortas na região de Botucatu - SP. Irriga, Botucatu, v.12, n.2, p.144-155, 2007.

FRÖDER, H.; MARTINS, C.G.; SOUZA, K.L.O.; LANDGRAF, M.; FRANCO, B.D.; DESTRO, M.T. Minimally processed vegetable salads: microbial quality evaluation. Journal Food Protection, Des Moines, v.70, n.5, p.1277-1280, 2007.

GÓMEZ ALDAPA, C.A.; RANGEL VARGAS, E.; CASTRO ROSAS, $J$. Frequency and correlation of some enteric indicator bacteria and salmonella in ready to eat raw vegetable salads from Mexican restaurants. Journal of Food Science, Chicago, v.78, n.8, p.1201-1207, 2013.

JAY, J.M. Microbiologia de Alimentos. 6. ed. Porto Alegre: Artmed, 2005. 711 p.

KONECKA-MATYJEK, E.; MACKIW, E.; KRYGIER, B.; TOMCZUK, K.; STOS, K.; JAROSZ, M. National monitoring study on microbial contamination of food-contact surfaces in hospital kitchens in Poland. Annals of Agricultural and Environmental Medicine, Inglaterra, v. 19, n.3, p.457-463, 2012.

KOZAK, G.K.; MACDONALD, D.; LANDRY, L.; FARBER, J.M. Foodborne outbreaks in Canada linked to produce: 2001 through 2009. Journal Food Protection, Estados Unidos, v.76, n. 1, p.173-183, 2013.

LEÓN, B.D.; GÓMEZ ALDAPA, C.A.; RANGEL VARGAS, E.; VÁZQUEZ BARRIOS, E.; CASTRO ROSAS, J. Frequency of indicator bacteria, Salmonella and diarrhoeagenic Escherichia coli pathotypes on ready to eat cooked vegetable salads from Mexican restaurants. Letters in applied microbiology, Oxford, v.56, n 6, p.414-420, 2013.

MAISTRO, L.C.; MIYA, N.T.N.; SANT'ANA, A.S.; PEREIRA, J.L. Microbiological quality and safety of minimally processed vegetables marketed in Campinas, SP-Brazil, as assessed by traditional and alternative methods. Food Control, Guildford, v.28, n.2, p.258-264, 2012. 
OLAIMAT, A. N.; HOLLEY, R.A. Factors influencing the microbial safety of fresh produce: a review. Food Microbiology, Londres, v.32, n. 1, p.1-19, 2012.

OYEBODE, O.; GORDON-DSEAGU, V.; WALKER, A.; MINDELL, J.S. Fruit and vegetable consumption and all-cause, cancer and CVD mortality: analysis of Health Survey for England data. Journal of Epidemiology e Community Health, Londres, v.68, n.9, p.856-862, 2014.

PINTO, G.R.; VEDANA, E.C.; ANJOS, M.; COZER, M.; FRANÇA, V.F. Avaliação da estrutura física e higiênico-sanitária de uma unidade de alimentação e nutrição na cidade de Francisco Beltrão - PR. Revista Multiciência, São Carlos, v.12, p.24-38, 2013.

RIBEIRO, D.T.; CORÇÃO, G.; NORMANN, C.A.M.; ALVES, M.K. Condições higiênico sanitárias e avaliação microbiológica das mãos de manipuladores em cozinhas residenciais no município de Caxias do Sul, RS. Revista Higiene Alimentar, Brasil, v.28, n.230/231, p.169-173, 2014.

ROCHA, A.N.F.; SOARES, R.P.; BEZERRA, M.L.S. Análise microbiológica de saladas cruas em restaurantes de Teresina - PI. Revista Interdisciplinar, Abaetetuba, v.7, n.2, p. 1 1-17, 2014.

RODRIGUES, D.G.; SILVA, N.B.M.; REZENDE, C.; JACOBUCCI, H.B.; FONTANA, E.A. Avaliação de dois métodos de higienização alimentar. Saúde e Pesquisa, Maringá, v.4, n.3, p.341-350, 2011.

SÃo PAULO (Estado). Portaria n. ${ }^{\circ} 5$ do Centro de Vigilância Sanitária, de 9 de abril de 2013 . Aprova o regulamento técnico sobre boas práticas para estabelecimentos comerciais de alimentos e para serviços de alimentação, e o roteiro de inspeção, anexo. Lex: coletânea de legislação e jurisprudência, São Paulo, Seção I, n.73, p.32-35, 2013.

SARKER, S.; HUSSAIN, M.S.; KHATUN, A.; HOSSAIN, M.A.; ALAM, M.K.; HOSSAIN, M.S. Development of gamma-irradiated low microbial vegetable salads for immunocompromised patients. Annals Food Science and Technology, Romênia, v.15, n.1, p.203-219, 2014.

SAS Institute. SAS/STAT User's Guide. Version 9.3, SAS Institute Inc., Cary, NC, 2011.

TABAN, B.M.; HALKMAN, A.K. Do leafy green vegetables and their ready-to-eat (RTE) salads carry a risk of foodborne pathogens? Anaerobe, Reino Unido, v.17, n.6, p.286-287, 2011.

WANG, X.; OUYANG, Y.; LIU, J.; ZHU, M.; ZHAO, G.; BAO, W.; HU, F.B. Fruit and vegetable consumption and mortality from all causes, cardiovascular disease, and cancer: systematic review and dose-response meta-analysis of prospective cohort studies. British Medical Journal, Londres, v.349, p.1-14, 2014. 